mechanism for the darkening effect of titania on the colour produced by iron in enamels ${ }^{3}$ ). Titania is a source of photo-activation of chemical processes, including some oxidation processes ${ }^{4}$. Less likely is a change in the state of oxidation of the titania itself. (Renz discusses the reduction of titania in light in the presence of certain organic liquids and reducing solutions ${ }^{5}$.) Among physical explanations, changes in the crystalline variety of titania present (cf the crystalline phases known to mineralogists as rutile, anatase and brookite) or in the grain-size of the titania do not seem very probable. Alteration in the degree of dispersion of some colloidal material suspended in the titania is another possibility (see, for example, the summary of Doelter's work given by $L_{e}{ }^{2}$ and the references provided by Clark $\theta^{6}$.

The above suggestions are by no means exhaustive, and the possibility of a connexion between the darkening of some titanium dioxide by light and the darkening of titania on heating should be borne in mind. Meanwhile, notice of the phenomena described may be of value to those workers interested in titanium and its compounds.

I wish to thank Dr. Harry W. Webb for reading through this letter.

Department of Pottery,

W. O. Williamson.

North Staffordshire Technical College,

Stoke-on-Trent. July 13.

'Parmelee, C. W., and Badger, A. E., J. Amer. Ceram. Soc 17, 1 (1934), last par. but one in the paper.

'Lee, O. I., Amer. Mineral., 21, 764 (1936).

'Lew, J. S., Sprechsaal, 67, 215 (1934).

'Goodeve, C. F'., Trans. Faraday Soc., 33, 340 (1937).

'Renz, C., Helv. Chim. Acta, 4, 961 (1921).

- Clarke, J. R., J. Soc. Glass Tech., 5, 155 (1921).

\section{A New Form of Resorcinol}

A NEW form of resorcinol has recently been investigated in this Laboratory which compares as follows with the structure already described by Robertson ${ }^{1}$.

$\begin{array}{lcc} & \alpha \text {-Resoreinol } & \beta \text {-Resorcinol (new form) } \\ \text { space group } & C_{2 v}^{a}(P n a) & C_{2 v}^{9}\left(P_{n} a\right) \\ \text { axes : } a & 10 \cdot 53 & 7 \cdot 91 \\ \quad b & 9 \cdot 53 & 12 \cdot 57 \\ c & 5 \cdot 66 & 5 \cdot 50 \\ \text { cell volume } & 568 \mathrm{~A} .^{3} & 547 \mathrm{~A}^{3} \\ \text { molecules per cell } & 4 & 4 \\ \text { molecular symmetry } & \text { none } & \text { none } \\ \text { calculated density } & \mathbf{1} \cdot 278 & 1 \cdot 327\end{array}$

The principal intensities and higher orders of single crystal X-ray photographs show that the molecules in the $\beta$-crystals have turned round to align themselves in the $b$-axis direction.

The new form is conveniently prepared by slow evaporation of benzene solutions at ordinary temperatures, using specially dried air $^{2}$. Vacuum sub. limation of resorcinol under certain conditions gives a preponderance of $\beta$-crystals, in large shiny flakes, which can easily be distinguished from the long needles of the $\alpha$-form. According to Lautz ${ }^{3}$, resorcinol undergoes a transformation above $70 \cdot 8^{\circ} \mathrm{C}$. into a denser modification, which is perhaps identical with the $\beta$-form.

The two forms of resorcinol are of considerable interest for the theory of intermolecular resonance, since the hydroxyl 'bonds' in the two structures need not necessarily be of the same length. Although this point can only be decided by a quantitative measurement of intensities of reflection, the manner of discovery of the $\beta$-form suggests that a difference in the hydroxyl bonds is quite possible. Repeated crystallization of resorcinol from $99 \cdot 6$ per cent 'heavy' water gives a deutero-resorcinol which, according to Munzberg ${ }^{4}$, has the structure $\mathrm{C}_{6} \mathrm{H}_{2} \mathrm{D}_{2}(\mathrm{OD})_{2}$. Whereas $\mathrm{C}_{6} \mathrm{H}_{4}(\mathrm{OH})_{2}$ when crystallized from boiling benzene gives good crystals of the $\alpha$-form, the deuterium compound gives poor feathery crystals of the $\beta$-form ; in one case a crystal was obtained which had the $\alpha$-structure at one end and the $\beta$-structure at the other. On vacuum sublimation, $\mathrm{C}_{6} \mathrm{H}_{2} \mathrm{D}_{2}(\mathrm{OD})_{2}$ again behaves differently in giving a preponderance of crystals with the $\alpha$-structure.

The thermodynamic relationship between the two forms and their magnetic anisotropy are being measured. The possibility of a transformation from one form to the other in the solid should perhaps be considered in connexion with temperature effects described by Nilakantan ${ }^{5}$.

\section{A. R. UBBELOHDE.}

J. Monteath Robertson.

Davy Faraday Laboratory, Royal Institution, London, W.1. July 5.

${ }^{1}$ Robertson, J. M., Proc. Roy. Soc., A, 157, 79 (1936).

'Ubbelohde, A. R., J. Chem. Soc., 972 (1933).

${ }^{3}$ Lautz, H., Z. phys. Chem., 84, 611 (1913).

'Munzberg, E., Z. phys. Chem., B, 33, 23 (1936).

Silakantan, P., Nature, 140. 30 (1937).

\section{Carbon-Halogen Distance in the Methyl Halides}

IN attempting to correlate the data on interatomic distances in polyatomic molecules, certain serious discrepancies have come to light between the spectroscopic method and the diffraction method as regards the carbon-halogen distances in the methyl halides. The differences are tabulated in Table 1. The reason that this had not been noticed earlier is that certain mistakes have been present in the deductions from the spectroscopic data and also that many new data are available. These results are particularly interesting when compared with the corresponding distances in the carbon tetrahalides,

TABLE 1.

\begin{tabular}{|l|c|c|c|c|}
\hline & $\begin{array}{c}\text { Old spectro- } \\
\text { scopic value }\end{array}$ & $\begin{array}{c}\text { New spectro- } \\
\text { scopic value }\end{array}$ & $\begin{array}{c}\text { Diffraction } \\
\text { value }^{2}\end{array}$ & $\begin{array}{c}\text { Value in } \\
\mathrm{CX}_{4}{ }^{2}\end{array}$ \\
\hline $\mathrm{CH}_{3} \mathrm{~F}$ & $1 \cdot 4$ & $1 \cdot 385 \pm 0.004$ & $1 \cdot 42 \pm 0.02$ & $1 \cdot 36 \pm 0.02$ \\
$\mathrm{CH}_{3} \mathrm{Cl}$ & $1 \cdot 8$ & $1.66 \pm 0.05$ & $1 \cdot 77 \pm 0.02$ & $1.755 \pm 0.005$ \\
$\mathrm{CH}_{3} \mathrm{Br}$ & $2 \cdot 0$ & $1.88 \pm 0.08$ & $2 \cdot 06 \pm 0.05$ & $1.93 \pm 0.03$ \\
$\mathrm{CH}_{3} \mathrm{I}$ & 2.05 & $2 \cdot 12 \pm 0.15$ & $2 \cdot 28 \pm 0.05$ & - \\
\hline
\end{tabular}

which are given in the last column. Thus it will be seen that, according to the diffraction method, in the methyl halides the carbon-halogen distance is always greater than, or equal to, the corresponding distance in the tetrahalides, whereas the spectroscopic method would seem to indicate that exactly the opposite is the case. The latter seems much more likely from consideration of the mutual repulsion of the halogen atoms in the tetrahalides.

Further support for this interpretation comes from an examination of the force constants for the C. halogen bond in the two cases. These are compared in Table 2, where it will be noticed that the force constant is always considerably larger in the methyl 